\title{
REGIONAL STRUCTURAL-LITHOLOGICAL1MODELING OF SEDIMENTARY COVER
}

\author{
D.P. Khrushchev \\ Institute of Geological Sciences of NAS of Ukraine, Kiev, Ukraine, E-mail: Khrushchov@hotmail.com \\ Doctor of geological-mineralogical sciences, professor, senior research worker.
}

The idea of the project is the construction of computer (digital) structural-lithological models (DSLM) of sedimentary cover for state territories on regional principle proceeding from the definition of geological region as a basic geostructural unit of Earth crust. Digital structural-lithological model - it is three-demensional computer representation of the geological objects, comprising it's structural and qualitative characteristics. Methodological principles, methods, available developments and modeling patterns are reflected to prove the feasibility of the project realization. Practical goal of modeling is the creation of integral geoinformatic foundation for multilateral cognitive image of an object and for information provision of all directories and kinds of human geological activity (R\&D) on multilateral use and protection (including geological hazards) of geological environment. The result achieved is obtaining of single united system of regional DSLM on state territorial level. The project proposed represents a part of conceptual compound project, the object of which has to comprise both sedimentary cover and magmatic, metamorphic formations. The achieved result of such a project is the developing of the integral digital structurallithological-petrological model of Earth crust as a whole.

Key words: sedimentary formations, sedimentary cover, computer modeling, geoinformatic system, geological environment use, geological environment protection.

\section{РЕГІОНААЬНЕ СТРУКТУРНО-АІТОАОГІЧНЕ МОАЕАЮВАННЯ OCAАОВОÏ ОБОАОНКИ}

\section{Д.П. Хрущов}

Інститут геологічних наук НАН України, Київ, Україна, E-mail: Khrushchov@hotmail.com Доктор геолого-мінералогічних наук, професор, старший науковий співробітник.

Ідея запропонованого проекту полягає в розробці комп'ютерних (цифрових) структурнолітологічних моделей осадової оболонки державних територій на регіональному принципі, виходячи із визначення геологічних регіонів як базових геоструктурних одиниць земної кори. Цифрова структурно-літологічна модель - об'ємне комп'ютерне відображення геологічного об'єкта, яке охоплює його структурні та якісні характеристики. Представляються методологічні принципи, методи, існуючі напрацювання та приклади моделювання для обґрунтування реалізації проекту. Практична задача моделювання - створення суцільної геоінформаційної основи для представлення всебічного гносеологічного образу об'єкта та інформаційного забезпечення всіх напрямів та видів геологічної діяльності з різнобічного використання та охорони (включаючи геологічні ризики) геологічного середовища. Очікуваний результат - отримання цільних регіональних цифрових структурно-літологічних моделей осадової оболонки на державно-територіальному рівні. Запропонований проект є частиною концептуальної складової проекту, об'єктом якого повинні бути як осадова оболонка, так і магматичні та метаморфічні утворення, тобто очікується розробка цифрової структурно-літолого-петрографічної моделі земної кори в цілому.

Ключові слова: осадова оболонка, осадові формації, комп'ютерне моделювання, геоінформаційні системи, використання надр, охорона геологічного середовища.

(C) D.P. Khrushchev, 2015 


\title{
РЕГИОНААЬНОЕ СТРУКТУРНО-АИТОАОГИЧЕСКОЕ МОАЕАИРОВАНИЕ ОСААОЧНОЙ ОБОАОЧКИ
}

\author{
Д.П. Хрущев
}

Институт геологических наук НАН Украины, Киев, Украина, E-mail: Khrushchov@hotmail.com Доктор геолого-минералогических наук, профессор, старший научный сотрудник.

Идея предлагаемого проекта состоит в разработке компьютерных (цифровых) структурнолитологических моделей осадочной оболочки государственных территорий на региональном принципе, исходя из определения геологических регионов как базовых геоструктурных единиц земной коры. Цифровая структурно-литологическая модель - объемное компьютерное отображение геологического объекта, охватывающее его структурные и качественные характеристики. Представляются методологические принципы, методы, имеющиеся наработки и примеры моделирования для обоснования реалистичности проекта. Практическая задача моделирования - создание цельной геоинформационной основы для всестороннего гносеологического образа объекта и информационного обеспечения всех направлений и видов геологической деятельности по разностороннему использованию и охране (включая геологические риски) геологической среды. Ожидаемый результат - получение целостных региональных цифровых структурно-литологических моделей осадочной оболочки на государственно-территориальном уровне. Предлагаемый проект является частью концептуального составного проекта, объектом которого должны быть как осадочная оболочка, так и магматические и метаморфические образования, т.е. ожидается разработка цифровой структурно-литолого-петрографической модели земной коры в целом. Ключевые слова: осадочная оболочка, осадочные формации, компьютерное моделирование, геоинформационные системы, использование недр, охрана геологической среды.

\section{Introduction}

Existing methods of geological activity information provision in the form of traditional maps of various visual forms and types, as well as various models (including computer ones, claiming 3D reflection) do not satisfy the requirements of modern technological progress in the field of technical activity. To overcome this discrepancy it is necessary to introduce new principles for the structure and matter composition of the Earth crust sedimentary cover reflection in the form of complex multiscale structural-lithological models that can be converted into target formats and provide the basis for multipurpose information provision of human geological activity.

The object of the work is a sedimentary shell of the biosphere, structured in the frames of sedimentary geological regions of Ukraine. Selecting an object is defined by the fact of the absolute predominance of sedimentary cover on the earth's surface and in the composition of the Earth crust as a whole, and localization in it mineral resources vast majority, including energy resources and groundwater, as well as its functional role in terms of underground and surface civil engineering, as well as all the main areas of social life.

The purpose of this publication - presentation of methodological principles, techniques, existing developments and examples of modeling to support a regional digital structurallithological modeling of sedimentary cover, intended for information supervision of all areas and types of human geological activity* associated with use and protection of the geological environment:

- With this objective, we have set the following tasks:

- presentation of existing premises, development, global trends and analogies;

- presentation of the methodological framework, methods and opportunities of the digital structural-lithological modeling;

- demonstrations of modeling examples;

* Geological activity is a set of actions of geological environment (medium) management. Geological management is a set of actions of it's multilateral use and protection, including geoecological hazards (i.e. actions for their mitigation and consequences liquidation). 
- designation of the expected results, strategies and principles of the project implementation.

The planned results of the project realization is to obtain a different scale digital structural-lithological models of sedimentary cover of geological regions and their structural elements of various ranks, including promising geological objects, in Ukraine.

\section{The idea, existing developments, global trends and analogues}

The idea is to transform the development of technology and experience in digital structural and lithological models (DSLM) development into regional, zonal and local scales, to develop DSLM for entire volume of sedimentary cover of geological regions with sedimentary filling.

Prerequisites, existing basis and obligatory conditions for project development. We consider the following items that define the reality of the problem statement for the conditions of Ukraine (and a majority of developed countries of the world community):

1. The presence of a methodological framework, methods set and computer technologies for DSLM constructing.

2. The presence of the final patterns of formational structure for all sedimentary regions of Ukraine.

3. Sufficient geological study of the territory of Ukraine sedimentary cover.

4. Convincing results of examples of traditional and digital structural-lithological modeling.

Below is a brief explanation of these items.

1. Methodology and methods of structurallithological modeling

Methodology and methods of structurallithological modeling of sedimentary formations - author's elaboration of interdepartmental scientific technical team (basic organization IGN NAS). The methodology of structural-lithological modeling is based on a joining of traditional formation analysis and copyright principles of sedimentary bodies structuring (using a systems approach) and computer technologies [Хрущев и др., 2010, etc.]. These papers highlight methodological techniques for digital structural-lithological modeling, which are based on the author's development of common approaches for static modeling of sedimentary formations geological objects.
2. Schemes of sedimentary regions formational structure

For all sedimentary regions of Ukraine there exist schemes of sedimentary cover formational dismemberment.

Below is a list of sedimentary regions with bibliographic attribution of the most famous patterns of formational dismemberment.

Dnieper-Donets depression (DDD): A.E. Lukin [Лукин, 1997] (28 formations are single don't ); V.S. Antipov, 1997 and others.

Donets Basin: V.S. Popov (1964), I.A. Maidanovich, A.J. Radziwill [Майданович, Радзивил, 1984] et al.

Ukrainian shield (US): M.D. Elyanov [Эльянов, 1975], A.A. Goyzhevsky [Гойжевський, 1975].

Volyn-Azov plate: M.I. Pavlyuk [Павлюк, Богаец, 1978]; L.G. Tkachuk et al. [Ткачук и др., 1975]; S.S. Kruglov (1988); G.N. Dolenko et al. [Доленко и др., 1984].

Crimea: M.I. Pavlyuk [Павлюк и др., 1973]; S.S. Kruglov et al. [1988]; Geology of the USSR [1969].

Folded Carpathians: S.S. Kruglov et al. (1988) V.N. Utrobin [Утробин, 1977]; L.T. Boychevskaya (1984).

Carpathian foredeep: from one (D.V. Gurzhiy [Гуржий, 1975]) to 11 formations (V.N. Utrobin [Утробин, 1977]) are singled out; D.P. Khrushchev revealed two formation (1988).

Transcarpatian depression: M.I. Petrashkevich [Petrashkevich, 1971]; I.V. Venglinskiy, V.A. Goretski [Венглинский, Горецкий, 1979]; D.P. Khrushchev (1988).

Dobrudzhea depression: M.I. Pavlyuk, A.T. Bogaets [Павлюк, Богаец, 1978], E.I. Patalakha (2002) and others.

Basic formational nomenclature and principal scheme of formational dismemberment of sedimentary cover for geological regions of Ukraine are listed in the monograph "The geological formations of oil and gas provinces of Ukraine" edited by G.N. Dolenko [Геологические..., 1984].

3. Sufficient geological study of sedimentary cover in Ukraine

This item needs no comments.

4. The credibility of the results of traditional and digital structural-lithological modeling at all levels of scale - from regional (small and medium-sized) to the local (large-scale) 
An example of the results of the traditional (two-dimensional) structural-lithological modeling at the regional scale may be structural and lithological model of red-terrigenous Stebnik formation (subformation), Carpathians foredeep (Khrushchov, 1988). The results obtained allowed to solve of following regional problems: against almost a century debate about the origin of Stebnik suite finally was realized its identification as polyfacial marine formational unit (subformation); the elaboration of cartographic (maps, profiles, block diagrams with reflection of lithofacies and facies spatial location) that allowed a prediction of lithofacies and facies favorable for localization of stratiform copper mineralization. This demand model can easily be digitized if demanded.

Examples of digital structural-lithological regional and zonal (i.e. more or less large part of the region) scales models are already quite a lot. Only within the contractual works of IGN NAS, commissioned by the State Geological Survey "The Atlas of salt formations of Ukraine" - a series of models have been developed. As their derivatives have been obtained: the structurallithological digital maps of salt formations of DDD, Carpathians foredeep, Dobrudzhea depression, and a map of the structural basis for Lower Molassa formation in Carpathians foredeep, reflecting its blocky structure. An example of the digital map for Kramatorskaya suite thicknesses DDD (executed by A.P. Lobasov on our order) is demonstrated (Fig. 1).

Examples of specialized regional and zonal modeling show structural and lithological maps - derivatives of the digital models of specific structural horizons in DDD, Carpatian foredeep and other regions of Ukraine, having been developed by A.P. Lobasov in the frames of the thematic works (state enterprise "Ukrnaftogaznauka").

Even more impressive are the results of large-scale digital modeling of promising local geological objects. As mentioned above, in the domestic and international practice already there exist many examples of large-scale modeling. In this paper we show examples of our latest developments.

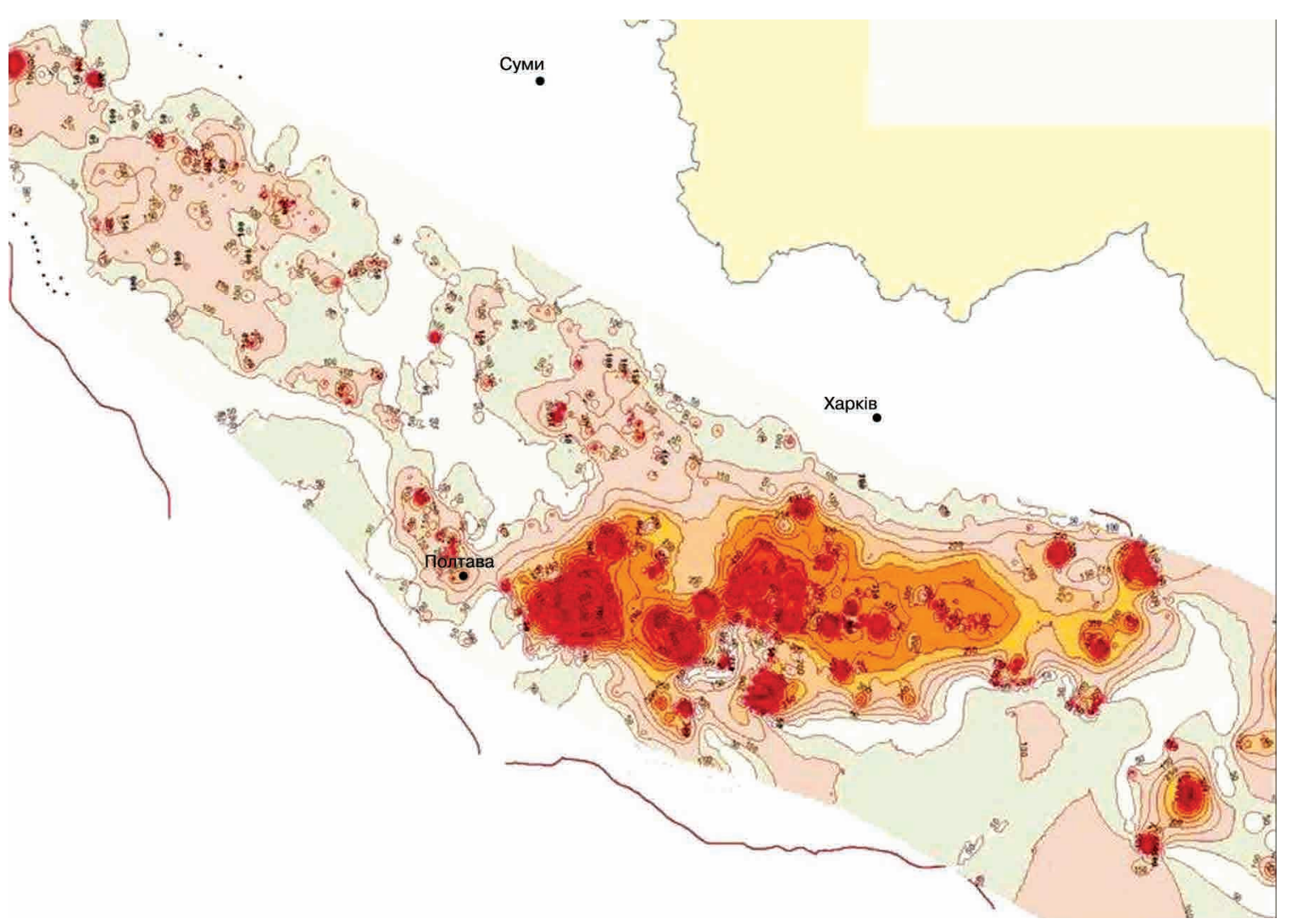

Fig. 1. Digital map of Kramatorskaya suit, Lower Permian, Dnieper-Donets depression (the derivative of DSLM, regional scale) 
Of course, the models of local geological objects are of target oriented character. By targeting one can single out three principal directions of the geological environment treatment: the use of natural resources; underground construction; geological environment protection (with subordinate directions) [Хрущев и др., 2012].

In the area of mineral resources use a number of DSLM promising objects amoung titanium-zirconium placers and gold bearing formations (alluvial deposits and weathering crust), saline formations (rock and potassium- magnesium salts) have been developed [Xpyщев и др., 2008; Khrushchov et al., 2010, etc.] . Two examples of the typical titanium-zirconium ores placer deposits are shown (Fig. 2, 3).

The DSLM construction helped to solve following the tasks aimed at development of deposits of titanium-zirconium ores: the determining of the spatial distribution of ore bodies (in the volume of the deposit massif), as well as the technological properties of the orebearing massif (the content of the clay material, granulometric parameters, unwanted mineral impurities - for example, siderite etc.);

Fig. 2. Zlobichy deposit of ilmenite. Distribution of ilmenite contents and automatic calculation of ilmenite resources in the crust of weathering (DSLM derivatives of local scale [Хрущев и др., 2008])

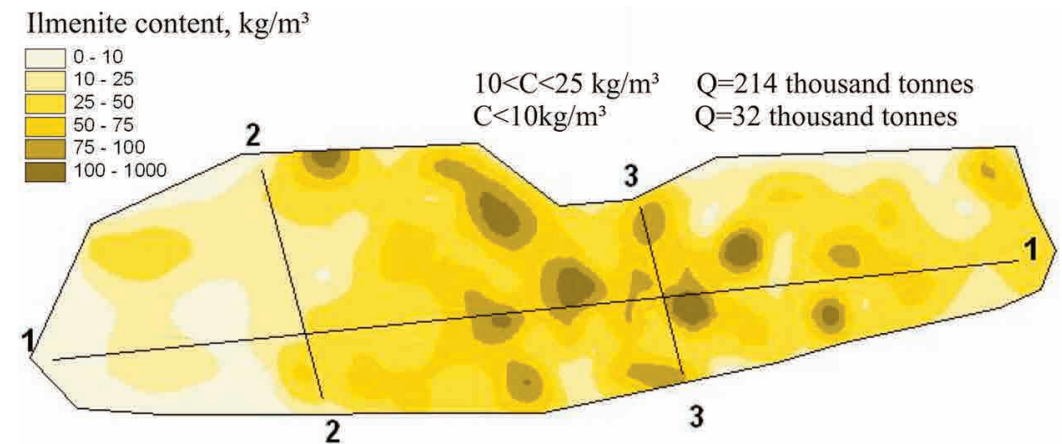

Content of ilmenite, $\mathrm{g} / \mathrm{m}^{3}$

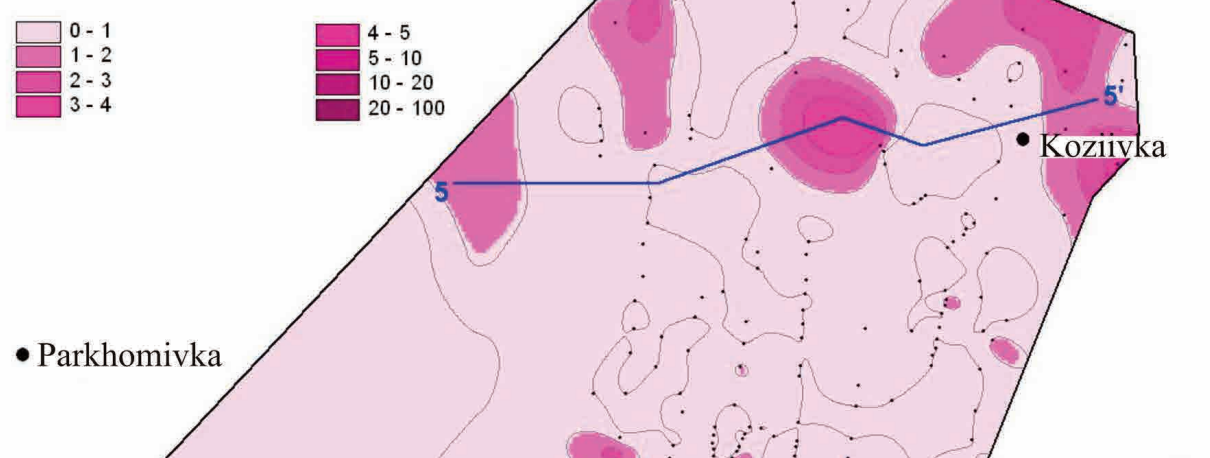

\section{3}

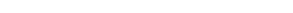
-2
-3
-4

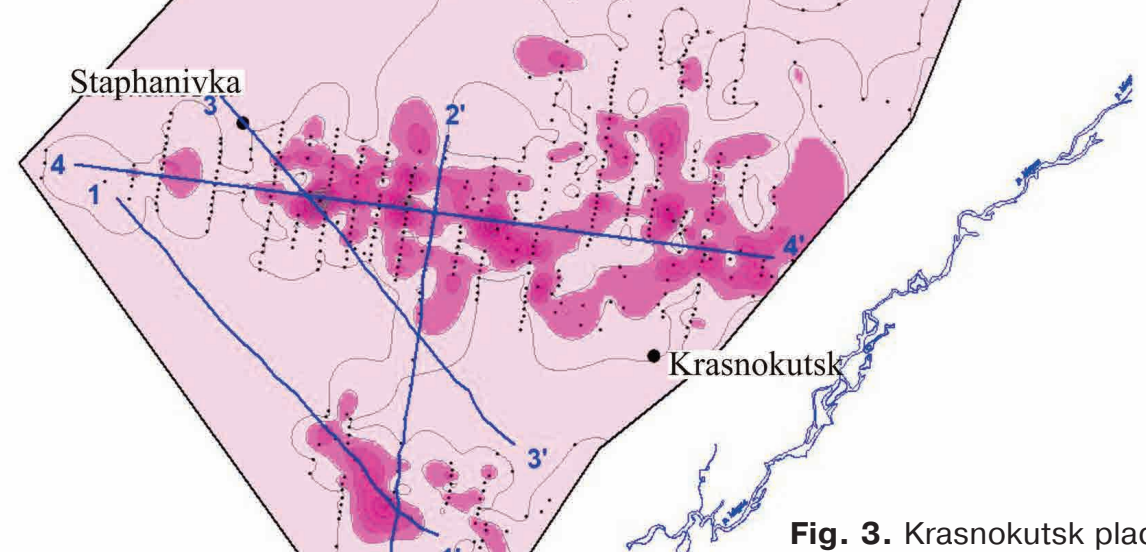

Fig. 3. Krasnokutsk placer deposits of titanium-zirconium ores. DSLM derivative of local scale. Distribution of ilmenite concentrations (by O. Kravchenko and A. Lobasov) 
automatic calculation of reserves of ore minerals (ilmenite, zircon, ilmenite conditional etc.) on the defined technological gradations; developing of methods for forecasting and estimation of deposits of the specific geological industrial type in neighboring territories.

In the direction of underground construction (subdirection - construction of underground storage facilities in rock salt) a number of DSLM have been developed for salt massifs of different structural occurrence forms (bedded, diapiric, folded) in several salt bearing regions of Ukraine. Traditional two-dimensional models for diapir structures have been con- structed, they can be easily converted into digital form by a special author's technique [Чaбанович, Хрущев, 2008 et al.].

An example of DSLM derivative (the map and profile) for Izmail area with designated site favorable for underground storage facility location, is shown (Fig. 4).

The modeling provides solution for the following tasks: selection and evaluation of underground storages sites; selection of salt massif volumes, favorable for storage caverns construction; providing a basis for calculating the long-term caverns sustainability and calculation of regulations for caverns construction.

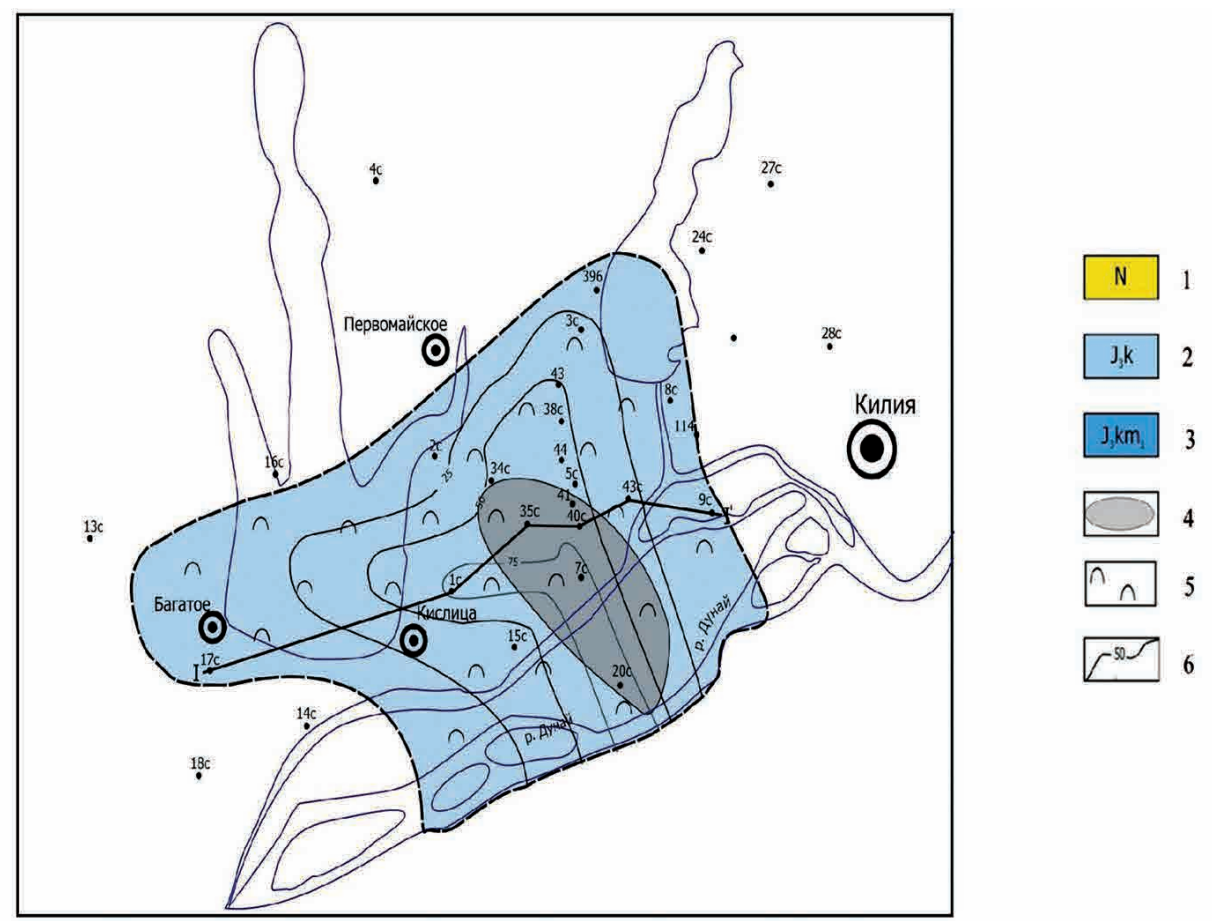

Geological section I-I

Horizontal scale 1:200 000

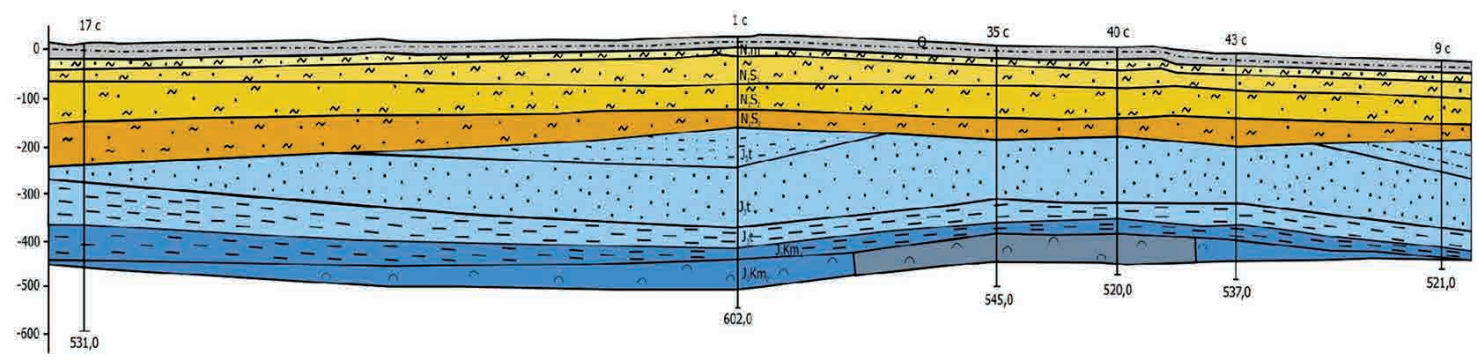

Fig. 4. The derivative of DSLM for Izmail area with salt massif favorable for underground construction

1 - Neogene system, loam, clay; 2 - Jurassic system Chadyr-Lunga suite, variegated terrigenous formation; 3 - Jurassic system, lower Kimmeridgian, clay, limestone, rock salt; 4 - the area favorable for underground construction; 5 - halite lithofacies complex; 6 - isopachs lines of salt massif. DSLM is developed by A.P. Lobasov on our order in the frames of the contract of the State Geological Service of Ukraine 
In the direction of the protection of the geological environment DSLM has been developed to solve complicated ecologicalmining-geological problems in areas degraded by salt industry mining activities. The visualizations of DSLM for Solotvyno salt dome (the area of ecological catastrophe occurrence) have been demonstrated. This catastrophe is expressed by deformations of the earth's surface, forming of a huge sinkholes and flood of two rock salt mines with underground cameras of Allergic hospital [Босевська, 2012; Хрущов та ін., 2010]. On the model profile of salt massif lithological types of rocks and functional types of rock salt with favorable (blue color gamut) and unfavorable (red color gamut) physical and mechanical properties are shown (Fig. 5). On the basis of this map the scheme with indicated sites, favorable for mining, was elaborated.

Development of DSLM provides a framework for constructing complex ecological mining-geological model for Solotvino rock salt deposits territory and a prognostic map of geohazards in this area.

Global trends analogies. There exist no direct analogues of the proposed direction in the world massif of $R \& D$ reports and scientific papers as well as patents. But there exist close general ideas and similar ideological trends "in the air". We have accepted the general idea of the International Geological Correlation Programme of UNESCO on Earth geospheres modeling, the idea of the global geology, global geochemical mapping. Certain ideological analogies in a sence of the total approach comprise: project of entire areal network drilling in Germany (Shneiderhen, 1933); the project of profile drilling in Kryvbas area (by Acad. N.P. Semenenko); the idea of complex geological surveys; finally, examples of formational geological maps (1983).

\section{Methodology, methods, procedural scheme \\ 2.1. Methodological principles}

The object of regional modeling is a sedimentary cover of geological regions with sedimentary formations filling.

The basic object unit of modeling - a geological formation as a major taxonomic element of regional tectonic-formational (by A.E. Lukin, 1997) complexes.
Formation is a historical-genetic association of rocks having been naturally formed in a particular geotectonic structure at a particular stage of its geodynamic development.

The subject of regional modeling are structural and qualitative characteristics of the formations (and their subdivisions).

The ultimate goal of regional modeling the development of DSLM for sedimentary cover of geological regions, i.e. their formation complexes filling.

This goal comprises three hierarchical levels of tasks, having different functional content: regional, zonal and local (corresponding to small, medium and large-scale levels) scale. Models at the regional level are mainly of general information character, zonal and local levels are target oriented.

Based on these definitions, methodological principles for regional TSSLM are formulated.

As mentioned above, the methodology of digital structural-lithological modeling is generally based on the combining of three traditional methodological directions: the foundations of classical formation analysis, principles of sedimentary bodies structuring using a systematic approach (in the author's development) and computer technologies in the proper target modification.

Foundations of formation analysis, representing the base of any direction of sedimentary formations studies, and the experience of its application are reflected in the huge number of classical and modern publications in the area of lithology and allied disciplines.

System approach, which is the methodological basis of our designated area of sedimentary formations units modeling, is reflected in studies Y.N. Karagodin, A.D. Armand, A.E. Lukin, V.A. Sadowski, A. Demetrius, Y.A. Kosygin, V.A. Solovyov and others. The structural aspect of formation analysis, which is the basic component of our development, is presented in the writings of D.V. Nalivkin, N.S. Shatsky, N.P. Kheraskov, L.B. Rukhin, A.E. Lukin, Y.N. Karagodin et al.

The principles of mathematical and computer modeling of formational units geological structure and composition are based on the method of variations calculus (V.I. Aronov, A.I. Vistelius, A.M. Volkov, F.A. Greybill, J.K. Griffiths, W. Krambeyn et al.) and spatially static analysis. 

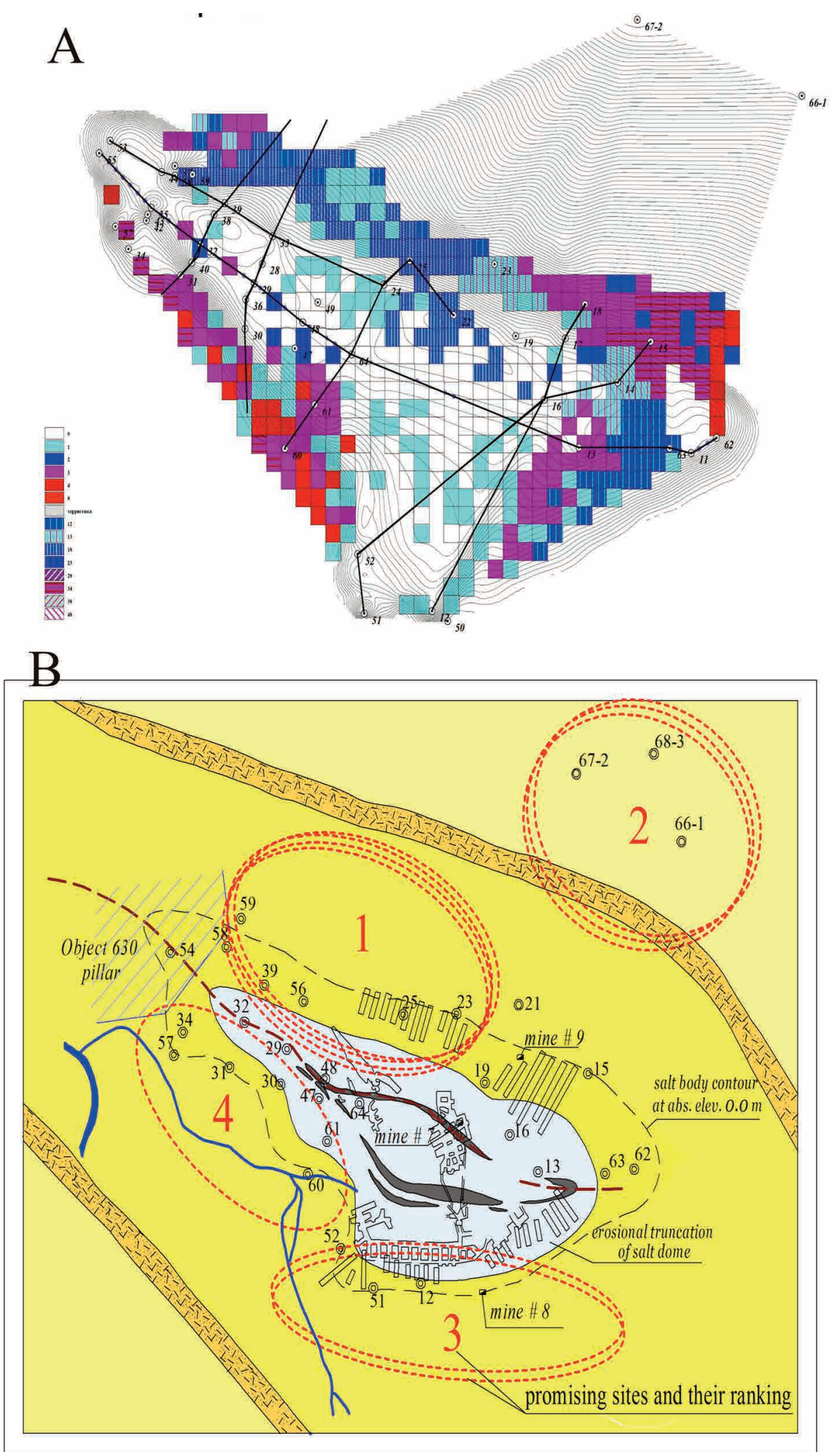

Fig. 5. A. DSLM visualization for salt body. Slice on the absolute elevation - $50 \mathrm{~m}$. 1:25 000 scale [Босевська, 2012]; B. The scheme of sites, favorable for exploitation (by L. Bosevska) 
By definition of Y.N. Karagodin (1985), the objectives of the structural and systemic analysis of geological systems are to define their structural organization, matter composition, functioning, development, origin and interaction with other systems. According to our approach, the basis for modeling has to include the elements of geological objects, that are related to it's structural organization and matter composition, as they can serve as a subject to formalization. DSLM are static, i.e. they reflect the state of the object at the moment (meanwhile the genetic, dynamic, and other aspects as are used as auxiliary means for current issues sollution). Static aspect displays primarily structural characteristics of the objects, namely the structural properties represent the basis for the model transformation into digital form.

\subsection{The methodology and procedure of modeling}

Modeling technique is basically based on the target development of general principles for geological objects sedimentary formations static modeling using copyright techniques for database compilation, specialized structuring of geological objects and modified technologies of computer processing.

The procedure for DSLM constructing includes two stages: preparation of the database and the proper modeling.

The database is a factual basis for modeling. It is essentially mapping and is developed in the form of geographic information systems. The database structure is traditional in nature (catalogs, maps, lithological sections and other cartographic materials, cards of lithological sections). Content of lithological sections card has to be modified depending on the formation type. For the lithological characteristics the nomenclature classifiers have to be compiled, the content of which is also determined by the type of formations.

The modeling procedure covers the following milestone tasks: preparation of input data, the development of a structural component of the model, lithological content of structural elements and computer processing.

Computer processing of the raw data bulk produced by the database covers three successive steps: equipment and data entry, computer processing by target largely copyright programs, model operation.
In preparing materials for computer processing primary goal (of research character) is the ascertaining of geological object structure. It is quite difficult to define the structural elements of geological object because methodological techniques differ for different tectonic styles of sedimentary formations - bedded (non dislocated) and weakly dislocated, folded, fold-block and diapiric. Nevertheless methodological techniques to solve these problems of modeling have been worked out [Хрущев и др., 2010, etc.].

Numerical models of structural and lithological parameters are stored in binary form in the structure of cartographic database software package «Geomapping». Input information of the system "Geomapping» is presented in the format shp GIS ArcView.

The resulting computer model, i.e., DSLM, is a virtual three-dimentional multilateral reflection of geological object, containing it's structural and qualitative characteristics.

\section{The program of the projected work}

Estimated range of researches has to be based upon interdepartmental cooperation, integration of geological and related disciplines, duration and multi-phase, multiple tasks and, in general, hi-tech. The program of researches planned is elaborated (Khrushchov, 2013). It is includes the schedule (milestones, issues and tasks, termes), main organizations - executors, results expected.

The customer and the owner of the materials obtained should serve the State Service of Geology of Ukraine.

\section{Conclusion}

The elaboration of above-cited project, concerning for the present only sedimentary cover, is only a part of planned compound project, which has to comprise both sedimentary cover and "crystalline" formation (i.e. magmatic and metamorphic). The results expected of this entire project has to be obtaining of DSLM for Earth Crust as a whole on regional principle for the territory of Ukraine.

The proposed project is aimed at solving the problem of information provision for all areas of geological activity associated with versatile use and protection of geological environment. 
The content of the project includes two levels of national strategic objectives in the field of geological environment management:

the level of state prerogatives in the field of general information provision for geological activity;

the level of state prerogatives in the field of information provision for projects and activities aimed at solving of specific practical issues of the geological environment management (investment projects on the use of the geological environment, state and mixed projects for the protection for geological environment protection, etc.).

The first level corresponds to the priority objectives of the project - the structural-lithological modeling of regional scale, having general information orientation.

The second level - the development of regional DSLM derivatives: models of the zonal and local scale, having a target destination.

The modeling of the first level is designed to provide the information for all geological $R \& D$ of regional level - State Geological Survey (primarily 1: 200 000), regional theme target studies, etc.

Modeling of the second level, as the target is aimed at information providing of all target areas of geological activity (target prognostic studies, search, exploration, exploitation of deposit, R\&D on the use of geological medium for underground construction, the same - measures for the protection of the geological environment).

Implementing of regional digital structurallithological modeling as a modern high-technology actually is an innovative advance in the field of information supervision of geological activity. At the same time, the results, having been partially demonstrated in this publication, justify the

\section{References}

1. Босевська Л.П. Структурно-літологічна характеристика соляних діапірів Закарпаття (у зв'язку з проблемами створення підземних сховищ, використання і охорони соляних ресурсів): автореф. дис. ... канд. геол. наук: спец. 04.00.21 «Літологія». Київ, 2012. 24 с.

Bosevska L.P., 2012. Structural and lithological characteristic of salt diapiris Transcarpathia (in relation to problems of underground storages construction, salt resources use and protection): Author. dis. ... Cand. Geol. Sci.: spec. 04.00.21 "Litology". Kyiv, 24 p. (in Ukrainian). realism of the project tasks and plans of ambitious scale.

Expected practical importance of the project results implementing is significant enhancing of the efficiency and reducing of content (and volume) of labor-intensive, material, energy and capital consuming traditional R\&D in all areas of the of geological environment management.

The project is long-term (and permanently acting in accordance with the principle of modeling), but the first practical results can be obtained in 2-3 years, that will mean the beginning of self-repayment consequently progressing. This implies the estimate of state budgetary financing. Expenditure funding will be made only in the first years of the project. Targeted basic research with the state budget financing should be conducted throughout the continuation of the project, but its self- repayment, expected in a few years, will consequently to increase due to increased effectiveness of all kinds of geological activity and, accordingly, a manifestation of the direct and indirect effects - economic, environmental, industrial, social.

The project is of a hi-tech character, which should be taken into account in its technical assessment.

Particular attention should be given for the international publicity of the project. Demonstrable progress of information technologies suggests the inevitability of regional geological modeling trends and ideas promoting, sooner or later, in one form or another in the world geosciences institutions. Manifestation of the Ukrainian initiative of this project may be a priority with the appropriate prestigious effect. Therefore, it seems appropriate to ensure international cooperation with the initial stages of its implementation.

2. Венглинский И.В., Горецкий В.А. Стратотипы миоценовых отложений Волыно-Подольской плиты Предкарпатского и Закарпатского прогибов. Киев: Наукова думка, 1979. 174 с.

Venglinskiy I.V., Goretski V.A., 1979. Stratotypes of Miocene in Volyn-Podolia plate, Carpathian and Transcarpathian depresions. Kiev: Naukova Dumka, 174 p. (in Russian).

3. Геологические формации нефтегазоносных провинций Украины / Доленко Г.Н., Бойчевская Л.Т., Галабуда Н.И. и др. Киев: Наукова думка, 1984. 232 с. 
Geological formation of oil and gas provinces in Ukraine / Dolenko G.N., Boychevskaya L.T., Galabuda N.I. et al. Kiev: Naukova Dumka, 1984, 232 p. (in Russian).

4. Геология СССР / гл. ред. акад. А.В. Сидоренко. Москва: Недра, 1969. Т. 8: Крым. Ч. 1. Геологическое описание. 575 с.

Geology of the USSR, 1969. (Editor-in-Chief Acad. A.V. Sidorenko). Moscow: Nedra, Vol. 8: Crimea. Part 1. Geological Description, 575 p. (in Russian).

5. Гойжевский А.А. Зависимость литологических особенностей и границ распространения мезо-кайнозойских отложений Украинского щита от тектонических движений. В кн.: Осадочные и осадочно-вулканогенные формации Украины и связанные с ними полезные ископаемые. Киев: Наукова думка, 1975. С. 145-151.

Goyzhevsky A.A., 1975. The dependence of lithological characteristics and boundaries of the Meso-Cenozoic deposits of the Ukrainian shield from tectonic movements. In: Sedimentary and sedimentary-volcanic formations of Ukraine and related minerals. Kiev: Naukova Dumka, p. 145-151 (in Russian).

6. Гуржий Д.В. Неогеновая молассовая формация Предкарпатского прогиба. Там же. C. 138-144.

Gurzhiy D.V., Neogene molasse formation of Carpathians foredeep. Ibid., p. 138-144 (in Russian).

7. Лукин А.Е. Литогеодинамические факторы нефтегазонакопления в авлакогенных бассейнах. Киев: Наукова думка, 1997. 223 с.

Lukin A.E., 1997. Litogeodinamical factors in the oil and gas forming in aulacogene basins. Kiev: Naukova Dumka, 223 p. (in Russian).

8. Майданович И.А., Радзивилл А.Я. Особенности тектоники угольных бассейнов Украины. Киев: Наукова думка, 1984. 119 с.

Maidanovich I.A., Radziwill A.Y., 1984. Tectonics of features coal basins of Ukraine. Kiev: Naukova Dumka, 119 p. (in Russian).

9. Павлюк М.И., Богаец А.Т. Тектоника и формации области сочленения Восточно-Европейской платформы и Скифской плиты. Киев: Наукова думка, 1978. 146 с.

Pavlyuk M.I., Bogaets A.T., 1978. Tectonics and formations of the junction area of the East European platform and the Scythian plate. Kiev: Naukova Dumka, 146 p. (in Russian).

10. Павлюк М.И., Копач И.П., Перыляк А.И. Формационный анализ и геологическая структура Равнинного Крыма: I Укр. литол. совещ. "Осадочные и осадочно-вулканогенные формации Украины и связанные с ними полезные ископаемые»: Тез. докл. Киев, 1973. С. 84-86.
Pavlyuk M.I., Kopacz I.P., Perylyak A.I., 1973. Formational analysis and geological structure of plain Crimea: I Ukr. litol. Symposium "Sedimentary and sedimentary-volcanic formations of Ukraine and related minerals": Proc. rep. Kiev, p. 84-86 (in Russian).

11. Петрашкевич М.И. Геологическое строение Закарпатского внутреннего прогиба. Стратиграфия. Донеогеновые образования. В кн.: Геологическое строение и горючие ископаемые Украинских Карпат. Москва: Недра, 1971. С. 219225. (Тр. УкрНИГРИ; Вып. 25).

Petrashkevich M.I., 1971. Geological structure of the Transcarpathian internal trough. Stratigraphy. Preneogene. In: Geology and Fuels of Ukrainian Carpathians. Moscow: Nedra, p. 219-225. (Prec. UkrNIGRI; Iss. 25) (in Russian).

12. Структурная карта по опорным горизонтам осадочного чехла платформенных территорий СССР / гл. ред. В.В. Семенович; М-во геологии СССР. Москва: ПГО «Центргеология», 1983.

Structure map of reference horizons of the sedimentary cover for platform territories of the USSR, 1983. Ministry of Geology of the USSR (Editor-inChief V.V. Semenovich). Moscow: PGO "Tsentrgeologiya" (in Russian).

13. Тектоника Украины. Москва: Недра, 1988. 253 с. (Тр. УкрНИГРИ; Вып. 36).

Tectonics of the Ukraine, 1988. Moscow: Nedra, 253 p. (Prec. UkrNIGRI; Iss. 36) (in Russian).

14. Ткачук Л.Г., Жовинский Э.Я., Литовченко Е.И. Домезозойские осадочные и осадочно-вулканогенные формации юго-западной окраины Восточно-Европейской платформы. В кн.: Осадочные и осадочно-вулканогенные формации Украины и связанные с ними полезные ископаемые. Киев: Наукова думка, 1975. C. 3-5.

Tkachuk L.G., Zhovinsky E.Y., Litovchenko E.I., 1975. Pre-Mesozoic sedimentary and sedimentaryvolcanic formations of south-western margin of the East European Platform. In: Sedimentary and sedimentary-volcanic formations of Ukraine and related minerals. Kiev: Naukova Dumka, p. 3-5 (in Russian).

15. Утробин В.Н. Глубинные структуры Предкарпатья, Карпат и Закарпатья. В кн.: Обоснование направлений поисков нефти и газа в глубиннозалегающих горизонтах Украинских Карпат. Киев: Наукова думка, 1977. С. 14-63.

Utrobin V.N., 1977. Deep structures of Carpathian for deep and Transcarpathia. In: Justification of directions for oil and gas exploration in deep horizons of Ukrainian Carpathians. Kiev: Naukova Dumka, p. 14-63 (in Russian). 
16. Хрущов Д.П., Босевська Л.П., Костів І.Ю. У чому ж сіль проблеми? Екологічна катастрофа у селі Солотвине. Надзвичайна ситуація. 2010. № 12. C. 18-21.

Khrushchev D.P., Bosevska L.P., Kostiv I.Yu., 2010. What is the salt of the problem? Ekological disaster in Solotvino. Nadzvychaina sytuatsia, № 12, p. 18-21 (in Russian).

17. Хрущев Д.П., Ковальчук М.С., Ремезова Е.A. Компьютерное отображение структуры, состава и состояния осадочных формаций: IV Міжнар. наук. конф. «Екологічна безпека: проблеми і шляхи вирішення»: Зб. наук. ст.: У 2 т. Харків: Райдер, 2008. Т. 1. С. 139-144.

Khrushchev D.P., Kovalchuk M.S., Remezova E.A., 2008. Computer mapping of the structure, composition and state of sedimentary formations: IV International Scientific Conf. "Ekological safety: the problems Roads Ahead": Collected papers: In 2 vol. Kharkiv: Ryder, vol. 1, p. 139-144 (in Russian).

18. Хрущев Д.П., Лобасов А.П., Гейченко М.В., Ремезова Е.А., Босевская Л.П., Кирпач Ю.В., Степанюк А.В. Структурно-литологические модели перспективных осадочных формаций. Мінер. ресурси України. 2010. № 4. С. 39-44.

Khrushchev D.P., Lobasov A.P., Geychenko M.V., Remezova E.A., Bosevskaya L.P., Kyrpach Yu.V., Stepaniuk A.V., 2010. Structural-lithological models of promising sedimentary formations. Mineralny resursy Ukrainy, № 4, p. 39-44 (in Russian).

19. Хрущев Д.П., Лобасов А.П., Ковальчук М.С. Целевые экспертные системы геологической направленности. Геол. журн. 2012. № 2 (339). С. 87-99.

Khrushchev D.P., Lobasov A.P., Kovalchuk M.S., 2012. Targeted expert systems of geological orientation. Geologichnyy zhurnal, № 2 (339), p. 8799 (in Russian).
20. Чабанович Л.Б., Хрущев Д.П. Научно-технические основы сооружения и эксплуатации подземных хранилищ в каменной соли. Киев: Варта, 2008. 304 c.

Chabanovich L.B., Khrushchev D.P., 2008. Scientific and technical basis for the construction and operation of underground storage facilities in rock salt. Kiev: Varta, 304 p. (in Russian).

21. Эльянов М.Д. Мощность и объем осадочных отложений Украинского щита. В кн.: Осадочные и осадочно-вулканогенные формации Украины и связанные с ними полезные ископаемые. Киев: Наукова думка, 1975. С. 75-82.

Elyanov M.D., 1975. The sickness and volume of Ukrainian Shield sediments. In: Sedimentary and sedimentary-volcanic formations of Ukraine and related minerals. Kiev: Naukova Dumka, p. 75-82 (in Russian).

22. Khruschov D.P., Lobasov O.P., Kovalchuk M.S. Digital structural-lithological models of sedimentary formations: a tool of informational-analytical supervision for exploitation and protection of mineral resources and geological environment: $A b$ stracts of International Conference "GeoDarmstadt 2010 - Geosciences Secure the Future". Darmstadt, Germany, 2010. Vol. 68. P. 306-307.

Khruschov D.P., Lobasov O.P., Kovalchuk M.S., 2010. Digital structural-lithological models of sedimentary formations: a tool of informational-analytical supervision for exploitation and protection of mineral resources and geological environment: Abstracts of International Conference "GeoDarmstadt 2010 - Geosciences Secure the Future". Darmstadt, Germany, vol. 68, p. 306-307 (in English).

Received March 11, 2015 